\title{
Analisis Pengaruh Retribusi Daerah Terhadap Pendapatan Asli Daerah Kabupaten Lombok Utara
}

\author{
Sutianingsih, Shinta Eka Kartika dan Widowati \\ Program Studi Akuntansi, Sekolah Tinggi Ilmu Ekonomi AMM, Mataram, Indonesia \\ E-Mail : shintaekakartika@gmail.com
}

\begin{abstract}
This study aims to determine the level of growth, effectiveness, contribution, and prediction of revenue (PAD) in North Lombok Regency. The data collection technique uses documentation, namely data on regional retribution and PAD for the years 2014-2019. Data analysis using descriptive analysis. The results show that the growth of regional retribution has increased in 2014 and 2015 by 76.3 percent and 72 percent, respectively. Meanwhile, in 2016-2019, the realization of regional retribution decreased by 56.4 percent, 9 percent, 4.7 percent and 55.3 percent respectively. The level of effectiveness of the collection of regional retribution in 2014 was 114.4 percent (very effective). Meanwhile, in 2015 and 2016, respectively 89.1 percent and 88.2 percent (less effective). And in 2017, 2018 and 2019 respectively 66.9 percent, 74 percent and 39.9 percent or included in the ineffective category. The contribution of regional retribution to PAD in 2014-2019 was 16.82 percent (not good), 22.83 percent (good enough), 7.88 percent, 6.16 percent, 6.76 percent and 2.69 percent respectively (not very good). The prediction of regional retribution for 2020-2022 is obtained by an average revenue for three years, namely IDR 19,474,844,122 or there will be an average increase of 33 percent per year. Meanwhile, the PAD prediction obtained an average revenue of IDR 342,948,257,802 or there will be an average increase of 33 percent per year.
\end{abstract}

Keywords: regional retribution; revenue (PAD); prediction
Submitted: DESEMBER 2020

Accepted: MARET 2021

\begin{abstract}
ABSTRAK
Penelitian ini bertujuan untuk mengetahui tingkat pertumbuhan, efektivitas, kontribusi, dan prediksi pendapatan asli daerah (PAD) di Kabupaten Lombok Utara. Teknik pengumpulan data menggunakan dokumentasi yaitu data retribusi daerah dan PAD tahun 2014-2019. Analisis data menggunakan analisis deskriptif. Hasil penelitian menunjukkan bahwa pertumbuhan retribusi daerah mengalami peningkatan pada tahun 2014 dan 2015 masing-masing sebesar 76,3 persen dan 72 persen. Sedangkan pada 20162019, realisasi retribusi daerah turun masing-masing sebesar 56,4 persen, 9 persen, 4,7 persen, dan 55,3 persen. Tingkat efektivitas pemungutan retribusi daerah tahun 2014 sebesar 114,4 persen (sangat efektif). Sedangkan pada tahun 2015 dan 2016 masingmasing 89,1 persen dan 88,2 persen (kurang efektif). Dan pada 2017, 2018 dan 2019 masing-masing 66,9 persen, 74 persen dan 39,9 persen atau termasuk dalam kategori tidak efektif. Kontribusi retribusi daerah terhadap PAD tahun 2014-2019 masing-masing sebesar 16,82 persen (kurang baik), 22,83 persen (cukup baik), 7,88 persen, 6,16 persen, 6,76 persen, dan 2,69 persen (tidak sangat baik). Prediksi retribusi daerah tahun 20202022 diperoleh dengan pendapatan rata-rata selama tiga tahun yaitu $\mathrm{Rp}$ 19.474.844.122 atau akan terjadi kenaikan rata-rata 33 persen per tahun. Sedangkan prediksi PAD memperoleh pendapatan rata-rata sebesar $\mathrm{Rp} 342.948 .257 .802$ atau akan terjadi peningkatan rata-rata sebesar 33 persen per tahun.
\end{abstract}

JIAKES

Kata Kunci: retribusi daerah; pendapatan (PAD); ramalan 
Regional

Retribution and

Revenue

$\underline{2}$

\section{PENDAHULUAN}

Otonomi daerah telah memberikan hak, wewenang, dan kewajiban kepada daerah otonom untuk mengatur dan mengurus sendiri urusan pemerintahan dan kepentingan masyarakat setempat dalam sistem Negara Kesatuan Republik Indonesia. Pemberian otonomi yang seluas-luasnya kepada daerah dimaksudkan untuk mempercepat terwujudnya kesejahteraan masyarakat melalui peningkatan pelayanan, pemberdayaan, dan peran serta masyarakat. Daerah juga diharapkan mampu meningkatkan daya saing dengan memperhatikan prinsip demokrasi, pemerataan, keadilan, keistimewaan dan kekhususan serta potensi dan keanekaragaman Daerah dalam sistem Negara Kesatuan Republik Indonesia. Hal ini telah diatur dalam Undang-Undang No. 23 Tahun 2014 tentang Pemerintahan Daerah yang merupakan pengganti Undang-Undang No. 32 Tahun 2004 tentang Pemerintahan Daerah, dan telah mengalami perubahan kedua dengan lahirnya Undang-Undang No. 9 Tahun 2015 tentang Perubahan Kedua atas Undang-Undang No. 23 Tahun 2014 tentang Pemerintahan Daerah.

Menurut Undang-Undang Nomor 33 Tahun 2004 Tentang Perimbangan Keuangan Antara Pemerintah Pusat Dan Pemerintahan Daerah, dalam rangka penyelenggaraan pemerintahan daerah, sumber penerimaan daerah dapat bersumber dari pendapatan daerah dan pembiayaan. Pendapatan daerah bersumber dari pendapatan asli daerah (PAD), dana perimbangan, dan lain-lain pendapatan daerah yang sah. Dengan demikian setiap daerah terus berupaya untuk meningkatkan penerimaan daerah melalui PAD, begitu pula dengan pemerintah kabupaten Lombok Utara sebagai salah satu kabupaten termuda di Provinsi Nusa Tenggara Barat. PAD merupakan pendapatan yang diperoleh daerah yang dipungut berdasarkan Peraturan Daerah sesuai dengan peraturan perundang-undangan yang bersumber dari pajak daerah, retribusi daerah, hasil pengelolaan kekayaan Daerah yang dipisahkan, dan lain-lain PAD yang sah. Berikut realisasi PAD Kabupaten Lombok Utara tahun 2014-2018:

Tabel 1 Realisasi PAD Kabupaten Lombok Utara 2014-2018 (dalam jutaan rupiah)

\begin{tabular}{|l|r|r|r|r|r|}
\hline \multicolumn{1}{|c|}{ Sumber PAD } & \multicolumn{1}{c|}{$\mathbf{2 0 1 4}$} & \multicolumn{1}{c|}{$\mathbf{2 0 1 5}$} & \multicolumn{1}{c|}{$\mathbf{2 0 1 6}$} & \multicolumn{1}{c|}{$\mathbf{2 0 1 7}$} & \multicolumn{1}{c|}{$\mathbf{2 0 1 8}$} \\
\hline Pajak daerah & 48.825 & 57.090 & 76.168 & 92.645 & 68.816 \\
\hline Retribusi daerah & 13.641 & 23.461 & 10.229 & 9.305 & 8.864 \\
\hline $\begin{array}{l}\text { Hasil Pengolahan Kekayaan } \\
\text { Daerah yang Dipisahkan }\end{array}$ & 1.807 & 2.544 & 4.073 & 5.073 & 3.793 \\
\hline Lain-Lain PAD yang Sah & 16.816 & 19.657 & 39.279 & 43.924 & 49.600 \\
\hline Jumlah PAD & $\mathbf{8 1 . 0 9 0}$ & $\mathbf{1 0 2 . 7 5 4}$ & $\mathbf{1 2 9 . 7 5 0}$ & $\mathbf{1 5 0 . 9 4 9}$ & $\mathbf{1 3 1 . 0 7 4}$ \\
\hline
\end{tabular}

Sumber: Laporan Realisasi Anggaran Lombok Utara Tahun 2014-2018

Berdasarkan Tabel 1. realisasi PAD pemerintah Kabupaten Lombok Utara terus meningkat dari tahun 2014 sampai dengan tahun 2017. Hal ini disebabkan karena ada peningkatan pendapatan dari pajak daerah, hasil pengelolaan kekayaan daerah yang dipisahkan dan lain-lain PAD yang sah. Pada tahun 2018 realisasi PAD pemerintah Kabupaten Lombok Utara mengalami penurunan karena adanya penurunan dari pajak daerah, retribusi daerah, dan hasil pengelolaan kekayaan daerah yang dipisahkan.

Realisasi retribusi daerah pemerintah Kabupaten Lombok Utara mengalami fluktuasi dari tahun 2014 sampai dengan tahun 2018. Realisasi tertinggi pada tahun 2015 sebesar Rp23.461.718.564 dan terendah pada tahun 2018 sebesar Rp8.864.449.689. Penurunan pendapatan dari retribusi daerah pada tahun 2018 disebabkan karena adanya gempa bumi yang melanda pulau Lombok, dan Lombok Utara merupakan daerah yang paling terdampak. Bencana gempa bumi yang terjadi pada akhir juli hingga bulan agustus 2018 cukup mempengaruhi pendapatan retribusi daerah karena sebagian besar fasilitas umum yang ada mengalami kerusakan. Berdasarkan catatan atas laporan keuangan pemerintah Kabupaten Lombok Utara tahun 2018, penurunan retribusi daerah ini terjadi karena penurunan retribusi dari jasa umum, jasa usaha atau pemberian izin tertentu seperti pelayanan kesehatan di puskesmas, penyediaan fasilitas pasar grosir berbagai jenis barang, fasilitas lainnya di lingkungan terminal, pelayanan pemeriksaaan kesehatan hewan sesudah dipotong, pelayanan jasa ke pelabuhan, pelayanan tempat rekreasi, 
pemberian izin untuk mendirikan suatu bangunan, dan pemberian izin usaha perikanan kepada badan. Dari jenis retribusi tersebut, yang mengalami penurunan terbesar adalah dari pelayanan tempat rekreasi, dimana target pada tahun 2018 sebesar Rp2.428.000.000, sedangkan realisasi hanya sebesar Rp274.06.000 atau tingkat efektivitas sebesar 11,29 persen.

Penurunan retribusi terbesar dari pelayanan tempat rekreasi ini sejalan dengan yang disampaikan oleh Kepala Dinas Pariwisata NTB Lalu Mohammad Faozol di Mataram, bahwa ketika gempa bumi terjadi, hampir sebagian besar wisatawan di Tiga Gili meminta untuk dievakuasi keluar dari ketiga pulau kecil tersebut menuju ke daratan Pulau Lombok dan selanjutnya memilih untuk pulang ketempat asalnya. Jumlah kunjungan wisatawan mengalami penurunan menjadi 2,8 juta wisatawan yang terdiri atas 1 juta wisatawan mancanegara dan 1,8 juta wisatawan nusantara, sehingga berimbas pada kehidupan masyarakat lokal yang bekerja di sektor pariwisata.

Retribusi daerah adalah pungutan sebagai pembayaran atas jasa umum, jasa usaha atau pemberian izin tertentu yang khusus disediakan oleh Pemerintah Daerah untuk kepentingan pribadi maupun badan (UU No. 28 Tahun 2009). Berkaitan dengan retribusi daerah, maka salah satu alternatif untuk meningkatkan PAD yaitu melalui retribusi pada sektor pariwisata yaitu pelayanan tempat rekreasi. Sektor pariwisata merupakan sektor yang berpotensi untuk meningkatkan dan memeratakan kesejahteraan masyarakat sesuai dengan kondisi, kekhasan, dan potensi unggulan yang dimiliki oleh daerah.

Kabupaten Lombok Utara memang memiliki pesona alam yang indah. Hal tersebut mendukung bertumbuhnya usaha di bidang pariwisata. Secara umum Kabupaten Lombok Utara memiliki beberapa atraksi alam yang sangat mempesona. Gili Trawangan dengan pasir putih dan under water scenery yang memukau, Gili Meno yang eksotis dengan danau air tawar di tengah-tengah pulau, dan Gili Air dengan terumbu karang yang yang beraneka ragam. Disamping itu juga tentu ada banyak air terjun seperti Sendang Gile, Tiu Kelep, Sekeper, Tiu Teja, Kerta Gangga, dan lain-lain. Wisata alam yang menjadi primadona adalah wisata pantai yang terpusat di Tiga Gili di Kecamatan Pemenang. Salah satu barometer perkembangan pariwisata di Kabupaten Lombok Utara adalah jumlah hotel dan restoran. Jumlah hotel pada tahun 2018 sebanyak 610 buah dengan kapasitas kamar sebanyak 5.528 kamar tidur. Jumlah wisatawan yang menginap di hotel di Lombok Utara pada tahun 2018 mencapai 599.540 wisatawan yang didominasi oleh wisatawan mancanegara sebanyak 511.840 wisatawan. Jumlah wisatawan tahun 2018 mengalami penurunan dibandingkan dengan tahun 2017 yang berjumlah 1.003.821 wisatawan (BPS Kabupaten Lombok Utara, 2019).

Hasil penelitian Sudarmana \& Sudiartha (2020) dan Sipakoly (2016) menemukan bahwa retribusi daerah berpengaruh signifikan terhadap PAD. Semakin meningkatnya penerimaan dari pajak dan retribusi daerah akan mengakibatkan semakin meningkat pula PAD yang akan diterima oleh pemerintah. Berbeda dengan hasil penelitian Safrita (2014) bahwa retribusi daerah baik itu retribusi jasa umum, retribusi jasa usaha, dan retribusi perizinan tertentu tidak berpengaruh signifikan terhadap PAD Kota Jayapura. Senada dengan hasil penelitian Yuliastuti dan Dewi (2017), kontribusi retribusi daerah terhadap PAD Kota Denpasar pada tahun 2011-2015 mencerminkan kontribusi penerimaan retribusi daerah yang masih sangat kurang. Sartika dkk (2019) capaian retribusi daerah Kabupaten/Kota Provinsi Sumatera Barat termasuk pada kriteria efektif, namun dari perhitungan pertumbuhan tergolong tidak berhasil, dan dari kontribusinya terhadap PAD termasuk pada kriteria kurang baik. Dengan demikian, berdasarkan fenomena yang telah diuraikan, peneliti termotivasi untuk mengetahui tingkat pertumbuhan retribusi daerah dan $\mathrm{PAD}$, tingkat efektivitas pemungutan retribusi daerah, kontribusi retribusi daerah terhadap PAD di Kabupaten Lombok Utara tahun 2014-2019, serta prediksi penerimaan retribusi daerah dan PAD di Kabupaten Lombok Utara tahun 2020-2022.

\section{Regional \\ Retribution and \\ Revenue}


Regional

Retribution and

Revenue

4

Menurut Peraturan Pemerintah Nomor 12 Tahun 2019 Tentang Pengelolaan Keuangan Daerah, Keuangan Daerah adalah semua hak dan kewajiban daerah dalam rangka penyelenggaraan Pemerintahan Daerah yang dapat dinilai dengan uang serta segala bentuk kekayaan yang dapat dijadikan milik daerah berhubung dengan hak dan kewajiban daerah tersebut. Dalam Undang-Undang Nomor 33 Tahun 2004 Tentang Perimbangan Keuangan Antara Pemerintah Pusat Dan Pemerintahan Daerah, sumber penerimaan daerah terdiri atas pendapatan daerah dan pembiayaan. Pembiayaan bersumber dari sisa lebih perhitungan anggaran daerah, penerimaan pinjaman daerah, dana cadangan daerah, hasil penjualan kekayaan daerah yang dipisahkan. Sedangkan pendapatan daerah bersumber dari:

1) Pendapatan Asli Daerah merupakan Pendapatan Daerah yang bersumber dari hasil Pajak Daerah, hasil Retribusi Daerah, hasil pengelolaan kekayaan Daerah yang dipisahkan, dan Lainlain Pendapatan Asli Daerah yang sah, yang bertujuan untuk memberikan keleluasaan kepada Daerah dalam menggali pendanaan dalam pelaksanaan otonomi daerah sebagai perwujudan asas Desentralisasi.

2) Dana Perimbangan merupakan pendanaan Daerah yang bersumber dari APBN yang terdiri atas Dana Bagi Hasil (DBH), Dana Alokasi Umum (DAU), dan Dana Alokasi Khusus (DAK). Dana Perimbangan selain dimaksudkan untuk membantu Daerah dalam mendanai kewenangannya, juga bertujuan untuk mengurangi ketimpangan sumber pendanaan pemerintahan antara Pusat dan Daerah serta untuk mengurangi kesenjangan pendanaan pemerintahan antarDaerah. Ketiga komponen Dana Perimbangan ini merupakan sistem transfer dana dari Pemerintah serta merupakan satu kesatuan yang utuh.

3) Lain-lain pendapatan daerah yang sah meliputi hibah, dana darurat dan penerimaan lainnya yang sesuai dengan peraturan perundang-undangan yang berlaku. Hibah adalah Penerimaan Daerah yang berasal dari pemerintah negara asing, badan/lembaga asing, badan/lembaga internasional, Pemerintah, badan/lembaga dalam negeri atau perseorangan, baik dalam bentuk devisa, rupiah maupun barang dan/atau jasa, termasuk tenaga ahli dan pelatihan yang tidak perlu dibayar kembali. Dana Darurat adalah dana yang berasal dari APBN yang dialokasikan kepada Daerah yang mengalami bencana nasional, peristiwa luar biasa, dan/atau krisis solvabilitas.

Menurut Undang-Undang Nomor 33 Tahun 2004 Tentang Perimbangan Keuangan Antara Pemerintah Pusat Dan Pemerintahan Daerah, Pendapatan Asli Daerah (PAD) adalah pendapatan yang diperoleh Daerah yang dipungut berdasarkan Peraturan Daerah sesuai dengan peraturan perundang-undangan. PAD bersumber dari pajak daerah, retribusi daerah, hasil pengelolaan kekayaan Daerah yang dipisahkan, dan lainlain PAD yang sah.

1) Pajak daerah

Menurut Undang-Undang Nomor 28 Tahun 2009 Tentang Pajak Daerah Dan Retribusi Daerah, Pajak daerah merupakan kontribusi wajib kepada Daerah yang terutang oleh orang pribadi atau badan yang bersifat memaksa berdasarkan Undang-Undang, dengan tidak mendapatkan imbalan secara langsung dan digunakan untuk keperluan Daerah bagi sebesar-besarnya kemakmuran rakyat. Jenis Pajak provinsi terdiri atas: Pajak Kendaraan Bermotor; Bea Balik Nama Kendaraan Bermotor; Pajak Bahan Bakar Kendaraan Bermotor; Pajak Air Permukaan; dan Pajak Rokok. Sedangkan jenis pajak kabupaten/kota terdiri atas: Pajak Hotel; Pajak Restoran; Pajak Hiburan; Pajak Reklame; Pajak Penerangan Jalan; Pajak Mineral Bukan Logam dan Batuan; Pajak Parkir; Pajak Air Tanah; Pajak Sarang Burung Walet; Pajak Bumi dan Bangunan Perdesaan dan Perkotaan; dan Bea Perolehan Hak atas Tanah dan Bangunan.

2) Retribusi daerah

Menurut Undang-Undang Nomor 28 Tahun 2009 Tentang Pajak Daerah Dan Retribusi Daerah, retribusi daerah adalah pungutan Daerah sebagai pembayaran atas jasa atau pemberian izin tertentu yang khusus disediakan dan/atau diberikan oleh Pemerintah 
Daerah untuk kepentingan orang pribadi atau Badan. Objek Retribusi adalah jasa umum, jasa usaha dan perizinan tertentu.

3) Hasil pengelolaan kekayaan Daerah yang dipisahkan

Hasil pengelolaan kekayaan Daerah yang dipisahkan meliputi bagian laba atas Revenue penyertaan modal pada perusahaan milik daerah/BUMD, milik pemerintah/BUMN dan perusahaan milik swasta.

4) Lain-lain PAD yang sah

Lain-lain PAD yang sah meliputi hasil penjualan kekayaan Daerah yang tidak dipisahkan, jasa giro, pendapatan bunga, keuntungan selisih nilai tukar rupiah terhadap mata uang asing, dan komisi, potongan, ataupun bentuk lain sebagai akibat dari penjualan dan/atau pengadaan barang dan/atau jasa oleh Daerah.

Menurut Undang-Undang Nomor 28 Tahun 2009 Tentang Pajak Daerah Dan Retribusi Daerah, retribusi daerah adalah pungutan Daerah sebagai pembayaran atas jasa atau pemberian izin tertentu yang khusus disediakan dan/atau diberikan oleh Pemerintah Daerah untuk kepentingan orang pribadi atau Badan. Jenis retribusi digolongkan menjadi tiga yaitu:

1) Retribusi Jasa Umum

Objek Retribusi Jasa Umum adalah pelayanan yang disediakan atau diberikan Pemerintah Daerah untuk tujuan kepentingan dan kemanfaatan umum serta dapat dinikmati oleh orang pribadi atau Badan. Subjek Retribusi Jasa Umum adalah orang pribadi atau Badan yang menggunakan/menikmati pelayanan jasa umum yang bersangkutan. Wajib Retribusi Jasa Umum adalah orang pribadi atau Badan yang menurut ketentuan peraturan perundang-undangan Retribusi diwajibkan untuk melakukan pembayaran Retribusi, termasuk pemungut atau pemotong Retribusi Jasa Umum. Prinsip dan sasaran dalam penetapan tarif Retribusi Jasa Umum ditetapkan dengan memperhatikan biaya penyediaan jasa yang bersangkutan, kemampuan masyarakat, aspek keadilan, dan efektivitas pengendalian atas pelayanan tersebut. Biaya yang dimaksud meliputi biaya operasi dan pemeliharaan, biaya bunga, dan biaya modal.

Jenis Retribusi Jasa Umum adalah: Retribusi Pelayanan Kesehatan; Retribusi Pelayanan Persampahan/Kebersihan; Retribusi Penggantian Biaya Cetak Kartu Tanda Penduduk dan Akta Catatan Sipil; Retribusi Pelayanan Pemakaman dan Pengabuan Mayat; Retribusi Pelayanan Parkir di Tepi Jalan Umum; Retribusi Pelayanan Pasar; Retribusi Pengujian Kendaraan Bermotor; Retribusi Pemeriksaan Alat Pemadam Kebakaran; Retribusi Penggantian Biaya Cetak Peta; Retribusi Penyediaan dan/atau Penyedotan Kakus; Retribusi Pengolahan Limbah Cair; Retribusi Pelayanan Tera/Tera Ulang; Retribusi Pelayanan Pendidikan; dan Retribusi Pengendalian Menara Telekomunikasi.

\section{2) Retribusi Jasa Usaha}

Objek Retribusi Jasa Usaha adalah pelayanan yang disediakan oleh Pemerintah Daerah dengan menganut prinsip komersial yang meliputi: pelayanan dengan menggunakan/memanfaatkan kekayaan Daerah yang belum dimanfaatkan secara optimal; dan/atau pelayanan oleh Pemerintah Daerah sepanjang belum disediakan secara memadai oleh pihak swasta. Subjek Retribusi Jasa Usaha adalah orang pribadi atau Badan yang menggunakan/menikmati pelayanan jasa usaha yang bersangkutan. Wajib Retribusi Jasa Usaha adalah orang pribadi atau Badan yang menurut ketentuan peraturan perundang-undangan Retribusi diwajibkan untuk melakukan pembayaran Retribusi, termasuk pemungut atau pemotong Retribusi Jasa Usaha. Prinsip dan sasaran dalam penetapan besarnya tarif Retribusi Jasa Usaha didasarkan pada tujuan untuk memperoleh keuntungan yang layak. Keuntungan yang layak yang dimaksud adalah keuntungan yang diperoleh apabila pelayanan jasa usaha tersebut dilakukan secara efisien dan berorientasi pada harga pasar.

Jenis Retribusi Jasa Usaha adalah: Retribusi Pemakaian Kekayaan Daerah; Retribusi Pasar Grosir dan/atau Pertokoan; Retribusi Tempat Pelelangan; Retribusi Terminal; Retribusi Tempat Khusus Parkir; Retribusi Tempat Penginapan/Pesanggrahan/Villa; 
Regional

Retribution and

Revenue

$\underline{6}$

Retribusi Rumah Potong Hewan; Retribusi Pelayanan ke pelabuhanan; Retribusi Tempat Rekreasi dan Olahraga; Retribusi Penyeberangan di Air; dan Retribusi Penjualan Produksi Usaha Daerah.

3) Retribusi Perizinan Tertentu

Objek Retribusi Perizinan Tertentu adalah pelayanan perizinan tertentu oleh Pemerintah Daerah kepada orang pribadi atau Badan yang dimaksudkan untuk pengaturan dan pengawasan atas kegiatan pemanfaatan ruang, penggunaan sumber daya alam, barang, prasarana, sarana, atau fasilitas tertentu guna melindungi kepentingan umum dan menjaga kelestarian lingkungan. Subjek Retribusi Perizinan Tertentu adalah orang pribadi atau Badan yang memperoleh izin tertentu dari Pemerintah Daerah. Wajib Retribusi Perizinan Tertentu adalah orang pribadi atau Badan yang menurut ketentuan peraturan perundang-undangan Retribusi diwajibkan untuk melakukan pembayaran Retribusi, termasuk pemungut atau pemotong Retribusi Perizinan Tertentu. Prinsip dan sasaran dalam penetapan tarif Retribusi Perizinan Tertentu didasarkan pada tujuan untuk menutup sebagian atau seluruh biaya penyelenggaraan pemberian izin yang bersangkutan. Biaya penyelenggaraan pemberian izin yang dimaksud meliputi penerbitan dokumen izin, pengawasan di lapangan, penegakan hukum, penatausahaan, dan biaya dampak negatif dari pemberian izin tersebut. Jenis Retribusi Perizinan Tertentu adalah: Retribusi Izin Mendirikan Bangunan; Retribusi Izin Tempat Penjualan Minuman Beralkohol; Retribusi Izin Gangguan; Retribusi Izin Trayek; dan Retribusi Izin Usaha Perikanan.

Pertumbuhan menunjukkan kemampuan daerah dalam mempertahankan dan meningkatkan penerimaan retribusi dari periode ke periode berikutnya. Untuk mengetahui laju pertumbuhan dari penerimaan retribusi daerah dapat dihitung dengan menggunakan rumus sebagai berikut (Halim, 2004:134):

Keterangan :

$$
G x=\frac{\mathrm{Xt}-\mathrm{X}(\mathrm{t}-1)}{\mathrm{X}(\mathrm{t}-1)} \times 100 \%
$$

$\mathrm{Gx}$ = Laju pertumbuhan retribusi daerah pertahun.

$\mathrm{Xt}=$ Realisasi penerimaan retribusi daerah pada tahun tertentu

$\mathrm{X}(\mathrm{t}-1)=$ Realisasi penerimaan retribusi daerah pada tahun sebelumnya

Efektivitas menggambarkan kemampuan pemerintah daerah dalam merealisasikan retribusi yang direncanakan dibandingkan dengan target yang ditetapkan berdasarkan potensi riil daerah. Kemampuan daerah dalam melaksanakan tugas dikategorikan efektif apabila rasio yang dicapai minimal 1 (satu) atau 100 persen, sehingga apabila rasio efektivitasnya semakin tinggi, menggambarkan kemampuan daerah semakin baik. (Halim, 2004:135).

Efektivitas adalah mengukur perbandingan antara realisasi penerimaan retribusi daerah dengan target penerimaan retribusi daerah. Retribusi daerah dikatakan efektif apabila tingkat efektivitas lebih besar atau sama dengan 100\%. Rumus pengukuran efektivitas (Halim, 2004:135).

$$
\text { Efektivitas }=\frac{\text { Realisasi Penerimaan Retribusi Daerah }}{\text { Target Penerimaan Retribusi Daerah }} \quad 100 \%
$$

Menurut Mahmudi (2016:141) nilai efektivitas dapat dikategorikan sebagai berikut:
a. Diatas $100 \%$
: Sangat efektif
b. $100 \%$
: Efektif
c. $90 \%-99 \%$
: Cukup efektif
d. $75 \%-89 \%$
: Kurang efektif
e. kurang dari $75 \%$ : Tidak efektif

Menurut Kamus Besar Bahasa Indonesia, kontribusi dapat diartikan sebagai sumbangan atau uang iuran. Sedangkan definisi dari retribusi daerah adalah pungutan Daerah sebagai pembayaran atas jasa atau pemberian izin tertentu yang khusus disediakan dan/atau diberikan oleh Pemerintah Daerah untuk kepentingan orang pribadi atau Badan (UU No. 28 Tahun 2009). Berdasarkan definisi tersebut apabila 
dihubungkan dengan retribusi daerah maka kontribusi retribusi daerah merupakan sumbangan yang diperoleh dari pungutan daerah atas pembayaran jasa atau pemberian izin tertentu yang disediakan oleh pemerintah daerah.

Kontribusi digunakan untuk mengetahui seberapa besar sumbangan retribusi daerah terhadap Pendapatan Asli Daerah. Kontribusi retribusi daerah dalam Pendapatan Asli Daerah dapat diperoleh dengan membandingkan realisasi penerimaan retribusi daerah dengan realisasi penerimaan Pendapatan Asli Daerah kemudian dikalikan 100\% (Halim, 2004:163). Untuk perhitungan kontribusi retribusi daerah terhadap Pendapatan Asli Daerah yaitu dengan menggunakan rumus:

Keterangan:

$$
P n=\frac{X n}{Y n} \times 100 \%
$$

Pn : kontribusi retribusi daerah tahun tertentu

$\mathrm{Xn}$ : realisasi retribusi daerah tahun tertentu

Yn : realisasi PAD tahun tertentu

Terdapat kriteria untuk menentukan apakah kontribusi retribusi daerah terhadap PAD sudah baik atau belum, kriteria tersebut diantaranya adalah: (Halim, 2004)
a. Diatas $50 \%$
: Sangat baik
b. $40 \%-50 \%$
: Baik
c. $30 \%-40 \%$
: Sedang
d. $20 \%-30 \%$
: Cukup baik
e. $10 \%-20 \%$
: Kurang baik
f. kurang dari $10 \%$ : Sangat kurang baik

Menurut Kamus Besar Bahasa Indonesia, prediksi dapat diartikan sebagai ramalan atau prakiraan. Prediksi atau peramalan pada dasarnya proses pengestimasian penerimaan retribusi pada periode mendatang yang dikaitkan dengan beberapa aspek. Prediksi atau peramalan memiliki arti penting baik bagi perusahaan maupun lembaga. Prediksi atau peramalan tersebut untuk memenuhi keperluan pembuatan perencanaan jangka panjang.

Prediksi merupakan peramalan apa yang akan terjadi pada waktu yang akan datang, sedang rencana, merupakan penentuan apa yang akan dilakukan pada waktu yang akan dilakukan. Prediksi dilakukan hampir semua orang baik itu pemerintah, pengusaha maupun orang awam. Masalah yang diramalkan pun bervariasi seperti perkiraan curah hujan, kemungkinan pemenang dalam pilkada, skor pertandingan atau tingkat inflasi (Subagyo, 2013). Prediksi bertujuan untuk mengurangi ketidakpastian terhadap sesuatu yang akan terjadi dimasa yang akan datang dengan meminimumkan kesalahan meramal yang diukur dengan Squared error, mean absolute, dan sebagainya. Tahapan atau langkah-langkah melakukan peramalan antara lain :

1. Menentukan masalah yang akan dianalisa dan mengumpulkan data yang dibutuhkan dalam proses analisis tersebut.

2. Menyiapkan data untuk diproses dengan benar

3. Menetapkan metode peramalan yang sesuai dengan data yang telah disiapkan.

4. Menerapkan metode yang sudah ditetapkan dan melakukan prediksi pada data untuk beberapa waktu kedepan.

5. Mengevaluasi hasil peramalan.

Metode Least Square (Kuadrat Kecil) adalah metode yang digunakan untuk menentukan persamaaan trend data yang mencakup analisis time series dengan dua kasus data genap dan ganjil (Subagyo, 2013). Persamaan trend dengan metode Least Square, yaitu:

$\mathrm{Y}^{\wedge}=a+b X$

Untuk mencari nilai $\mathrm{a}$ dan $\mathrm{b}$ dari persamaan trend dapat digunakan dua persamaan normal sebagai berikut :

$\Sigma Y=n . a+b . \Sigma X$

$\Sigma X Y=a . \Sigma X+b . \Sigma x^{2}$
Retribution and

Revenue 
Regional

Retribution and

Revenue
Keterangan :

$\mathrm{Y}^{\wedge}=$ data berkala $($ time series $)=$ taksiran data trend

$\mathrm{X}=$ Variabel waktu (hari, minggu, bulan atau tahun)

$\mathrm{a}=$ nilai trend pada tahun dasar

$\mathrm{b}=$ rata-rata pertumbuhan nilai trend pada tiap tahun

\section{METODOLOGI PENELITIAN}

Jenis penelitian adalah deskriptif karena memberikan gambaran tingkat pertumbuhan retribusi daerah dan $\mathrm{PAD}$, tingkat efektivitas pemungutan retribusi daerah, kontribusi retribusi daerah terhadap PAD dan prediksi penerimaan retribusi daerah dan PAD di Kabupaten Lombok Utara. Teknik pengumpulan data menggunakan dokumentasi berupa catatan jumlah target dan realisasi retribusi daerah dan PAD pada Laporan Realisasi Anggaran (LRA) Kabupaten Lombok Utara tahun 2014-2019 yang diperoleh dari Badan Pendapatan Daerah Kabupaten Lombok Utara.

Variabel penelitian adalah retribusi daerah dan Pendapatan Asli Daerah (PAD).

Retribusi daerah merupakan pungutan sebagai pembayaran atas jasa umum, jasa usaha atau pemberian izin tertentu yang khusus disediakan oleh Pemerintah Daerah untuk kepentingan pribadi maupun badan (UU No. 28 Tahun 2009). Jumlah retribusi daerah yang dimaksud dalam penelitian ini adalah realisasi retribusi daerah pada Laporan Realisasi Anggaran (LRA). PAD merupakan pendapatan yang diperoleh daerah yang dipungut berdasarkan Peraturan Daerah yang bersumber dari pajak daerah, retribusi daerah, hasil pengelolaan kekayaan Daerah yang dipisahkan, dan lain-lain PAD yang sah. Jumlah PAD yang dimaksud dalam penelitian ini adalah realisasi PAD pada Laporan Realisasi Anggaran (LRA). Teknik analisis data yang digunakan adalah dengan menggunakan analisis deskriptif.

\section{HASIL DAN PEMBAHASAN}

Tingkat Pertumbuhan Retribusi Daerah dan PAD

Tingkat pertumbuhan retribusi daerah mengalami pertumbuhan yang negatif dari tahun 2017 sampai dengan tahun 2019. Tahun 2013 dijadikan sebagai tahun dasar dalam menentukan tingkat pertumbuhan retribusi daerah tahun 2014. Pada tahun 2013 jumlah realisasi retribusi daerah sebesar Rp7.739.619.801, sedangkan pada tahun 2014 realisasi retribusi daerah sebesar Rp13.641.497.678. Artinya pada tahun 2014 mengalami pertumbuhan yang positif (kenaikan) sebesar 76,3 persen dari tahun 2013. Hal yang sama terjadi pada tahun 2015, jumlah realisasi retribusi daerah sebesar Rp23.461.718.564, artinya pada tahun 2015 mengalami kenaikan sebesar 72 persen dari realisasi retribusi daerah tahun 2014. Sementara itu, dari tahun 2016 sampai dengan tahun 2019, realiasi retribusi daerah mengalami pertumbuhan yang negatif (penurunan) masing-masing sebesar 56,4 persen pada tahun 2016, 9 persen tahun 2017, 4,7 persen tahun 2018 dan penurunan tertinggi pada tahun 2019 sebesar 55,3 persen.

Berdasarkan catatan atas laporan keuangan tahun 2016, penurunan retribusi daerah tahun 2016 disebabkan oleh penurunan retribusi dari pelayanan kesehatan di puskesmas, retribusi pemanfaatan ruang untuk menara telekomunikasi, retribusi kendaraan bermotor, retribusi penyediaan fasilitas pasar grosir, retribusi pelayanan tempat khusus parkir, dan retribusi pemberian izin untuk mendirikan suatu bangunan. Sedangkan penurunan retribusi daerah tahun 2017 disebabkan oleh penurunan retribusi dari pelayanan kesehatan di puskesmas, retribusi fasilitas lainnya di lingkungan terminal, retribusi pelayanan tempat khusus parkir, retribusi pelayanan pemeriksaan kesehatan hewan sesudah dipotong, retribusi pelayanan jasa ke pelabuhan, retribusi tempat rekreasi, retribusi pemberian izin untuk mendirikan suatu bangunan, dan retribusi pemberian izin untuk melakukan penjualan minuman beralkohol.

Penurunan retribusi daerah tahun 2018 disebabkan oleh penurunan retribusi dari penyediaan pelayanan parkir, retribusi pelayanan pasar los, retribusi kendaraan bermotor, retribusi penyediaan fasilitas pasar grosir, retribusi fasilitas lainnya di 
lingkungan terminal, retribusi pelayanan tempat khusus parkir, retribusi pelayanan pemeriksaan kesehatan hewan sesudah dipotong, retribusi pelayanan jasa ke pelabuhan, retribusi tempat rekreasi, retribusi pemberian izin trayek, dan retribusi pemberian izin usaha perikanan. Penurunan terbesar berasal dari retribusi pelayanan jasa ke pelabuhan karena pasca gempa pemerintah Kabupaten Lombok Utara tidak lagi melakukan penarikan retribusi di pelabuhan bangsal dan banyak obyek wisata pasca gempa tidak aktif kembali.

Sementara itu, tahun 2019 merupakan masa pemulihan bagi Kabupaten Lombok Utara pasca gempa. Penurunan retribusi daerah pada tahun 2019 disebabkan oleh penurunan retribusi dari pelayanan kesehatan di puskesmas, retribusi pemanfaatan ruang untuk menara telekomunikasi, retribusi tempat rekreasi, retribusi pemberian izin untuk mendirikan suatu bangunan, dan retribusi pemberian perpanjangan IMTA kepada pemberi kerja tenaga kerja asing. Penurunan retribusi dari pemberian perpanjangan IMTA kepada pemberi kerja tenaga kerja asing (TKA) disampaikan juga oleh Kepala Dinas Tenaga Kerja, PMPTSP KLU, Agus Tisno, S.Sos., melalui Kepala Bidang Tenaga Kerja, Furqon, pada https://www.suarantb.com/ bahwa pengurangan TKA pascagempa cukup signifikan. Sebelum gempa, jumlah TKA yang tercatat sejumlah 170 orang. Namun pascagempa, jumlahnya tersisa sekitar 36 orang.

Sementara itu tingkat pertumbuhan PAD mengalami pertumbuhan yang positif (kenaikan) dari tahun 2014 sampai dengan tahun 2017. Tahun 2013 dijadikan sebagai tahun dasar dalam menentukan tingkat pertumbuhan PAD tahun 2014. Pada tahun 2013 jumlah realisasi PAD sebesar Rp49.619.934.763, sedangkan pada tahun 2014 realisasi PAD sebesar Rp81.090.502.360. Artinya pada tahun 2014 mengalami kenaikan sebesar 63,4 persen dari tahun 2013. Tahun 2015 sampai dengan tahun 2017 mengalami kenaikan masing-masing sebesar 26,7 persen pada tahun $2015,26,3$ persen pada tahun 2016 dan 16,3 persen pada tahun 2017. Namun pada tahun 2018 mengalami penurunan sebesar 13,2 persen dari tahun 2017 dan tahun 2019 kembali mengalami pertumbuhan yang positif sebesar 12,4 persen. Penurunan PAD pada tahun 2018 disebabkan karena adanya penurunan dari pajak daerah, retribusi daerah, dan hasil pengelolaan kekayaan daerah yang dipisahkan. Pendapatan dari pajak daerah pada tahun 2017 sebesar Rp92.645.659.869, namun pada tahun 2018 turun menjadi Rp68.816.145.279. Begitu pula dengan pendapatan dari retribusi daerah pada tahun 2017 sebesar Rp9.305.407.983, namun pada tahun 2018 turun menjadi Rp8.864.449.689. Pendapatan dari hasil pengelolaan kekayaan daerah yang dipisahkan pada tahun 2017 sebesar Rp5.073.723.177 namun pada tahun 2018 turun menjadi Rp3.793.981.094.

Penurunan PAD dari pajak daerah disampaikan juga oleh Bupati Lombok Utara, H. Najmul Akhyar dalam harian https://www.antaranews.com/, bahwa dari 1.216 potensi pajak meliputi hotel, restoran, hiburan dan parkir, terdapat 456 potensi pajak yang tutup sejak bulan agustus sampai dengan desember 2018. Selaras dengan apa yang disampaikan oleh Kepala Bagian Manajemen Krisis Kepariwisataan, Kementerian Pariwisata dalam Puspitasarie dkk (2019) bahwa kunjungan wisatawan mancanegara (wisman) yang datang melalui pintu Bandara Internasional Lombok mengalami penurunan yang drastis. Kedatangan wisatawan pasca gempa Lombok dalam kurun waktu satu bulan (6 Agustus - 6 September 2018) seharusnya sebanyak 13.000 wisatawan, namun realisasi hanya 3.000 wisatawan.

\section{Tingkat efektivitas pemungutan retribusi daerah}

Tingkat efektivitas pemungutan retribusi daerah mengalami penurunan pada tahun 2015 sampai dengan tahun 2019. Tingkat efektivitas pemungutan retribusi daerah tahun 2014 sebesar 114,4 persen, tergolong sangat efektif. Sedangkan tingkat efektivitas pemungutan retribusi daerah tahun 2015 dan 2016 masing-masing sebesar 89,1 persen dan 88,2 persen atau termasuk kategori kurang efektif. Tingkat efektivitas pemungutan retribusi daerah tahun 2017, 2018 dan 2019 masing-masing sebesar 66,9 persen, 74 persen dan 39,9 persen atau termasuk kategori tidak efektif. Hasil penelitian ini tidak mendukung penelitian Sartika dkk (2019) yang menemukan bahwa capaian retribusi daerah di Kabupaten/Kota Provinsi Sumatera Barat tahun 2012-2016 termasuk pada
Regional
Retribution and

Revenue

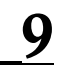


Regional

Retribution and

Revenue

10

kriteria efektif. Sedangkan Yuliastuti dan Dewi (2017) juga menyimpulkan bahwa tingkat efektivitas retribusi daerah Kota Denpasar pada tahun 2011-2015 mencerminkan penerimaan yang sangat efektif.

Tingkat efektivitas ini menggambarkan kemampuan pemerintah daerah Kabupaten Lombok Utara dalam merealisasikan retribusi daerah yang direncanakan dibandingkan dengan target yang ditetapkan berdasarkan potensi riil daerah. Tidak efektivnya pemungutan retribusi daerah disebabkan karena belum maksimalnya pengelolaan retribusi daerah seperti kurangnya ketersediaan sarana pendukung penagihan retrebusi daerah, belum optimalnya pelaksanaan Perda yang berkaitan dengan retribusi yang penerimaannya dikelola oleh masing-masing SKPD lingkup kabupaten dan kurangnya koordinasi secara sinergis dengan SKPD Penghasil, serta kurangnya kesadaran masyarakat dalam membayar retribusi daerah. Sejalan dengan hasil penelitian Astini dkk (2017) bahwa penyebab tidak tercapainya target pemungutan retribusi adalah pemungutan retribusi yang belum optimal dan kurangnya kesadaran wajib retribusi dalam membayar retribusi serta sarana dan prasarana yang kurang memadai.

\section{Kontribusi Retribusi Daerah terhadap PAD}

Kontribusi retribusi daerah terhadap PAD pada tahun 2014 sampai dengan tahun 2019 masing-masing sebesar 16,82 persen, 22,83 persen, 7,88 persen, 6,16 persen, 6,76 persen dan 2,69 persen. Kontribusi retribusi daerah terhadap PAD tahun 2014 termasuk kategori kurang baik, kontribusi retribusi daerah terhadap PAD tahun 2015 termasuk kategori cukup baik, dan kontribusi retribusi daerah terhadap PAD tahun 2016 sampai dengan 2019 termasuk kategori sangat kurang baik karena kurang dari 10 persen.

Kontribusi retribusi daerah terhadap PAD pada Kabupaten Lombok Utara tahun 2014 sampai dengan 2019 berada pada kategori sangat kurang baik sampai kategori cukup baik. Hal ini sejalan dengan hasil penelitian Sartika dkk (2019) yang menunjukkan bahwa kontribusi retribusi daerah terhadap Pendapatan Asli Daerah pada Kabupaten/Kota Provinsi Sumatera Barat tahun 2012-2016 termasuk pada kriteria kurang baik. Yuliastuti dan Dewi (2017) juga menyimpulkan bahwa kontribusi retribusi daerah terhadap Pendapatan Asli Daerah Kota Denpasar pada tahun 2011-2015 mencerminkan kontribusi penerimaan retribusi daerah yang masih sangat kurang.

\section{Prediksi Penerimaan Retribusi Daerah dan PAD}

Prediksi penerimaan retribusi daerah dan PAD tahun 2020 sampai dengan tahun 2022 menunjukkan bahwa prediksi penerimaan retribusi daerah untuk tahun 2020 sampai dengan 2022 masing-masing sebesar Rp20.726.638.765, Rp19.474.844.122, dan Rp18.223.049.480. Sementara itu prediksi penerimaan PAD untuk tahun 2020 sampai dengan 2022 masing-masing sebesar Rp327.193.209.514, Rp342.948.257.802, dan Rp358.703.306.090. Prediksi penerimaan retribusi daerah untuk tahun 2020 sampai dengan tahun 2022 diperoleh rata-rata penerimaan untuk 3 (tiga) tahun yakni Rp19.474.844.122 atau akan terjadi peningkatan rata-rata sebesar 33 persen per tahun. Demikian halnya dengan prediksi penerimaan PAD untuk tahun 2020 sampai dengan tahun 2022 diperoleh rata-rata penerimaan untuk 3 (tiga) tahun yakni Rp342.948.257.802 atau akan terjadi peningkatan rata-rata sebesar 33 persen per tahun. Dengan melihat rata-rata prediksi penerimaan retribusi daerah dan $\mathrm{PAD}$, maka kontribusi retribusi daerah terhadap PAD sebesar 6 persen atau termasuk kriteria sangat kurang baik, walaupun dari sisi jumlah penerimaan retribusi mengalami peningkatan dari tahun sebelumnya. Hasil penelitian ini sejalan dengan penelitian Kisnawati dan Irianto (2016) bahwa pertumbuhan PAD Kabupaten Lombok Utara selama tahun 2009. 2015 masih rendah dari sisi kuantitasnya, begitu pula dengan rata-rata estimasi penerimaan PAD untuk tahun 2016-2020 juga rendah walaupun diprediksikan penerimaan PAD dari segi persentase akan meningkat rata-rata sebesar 20 persen pertahun

\section{PENUTUP}

Berdasarkan hasil penelitian dan pembahasan yang telah dilakukan, maka dapat ditarik simpulan sebagai berikut: 
1. Realisasi penerimaan retribusi daerah mengalami kenaikan pada tahun 2014 sebesar 76,3 persen dan tahun 2015 sebesar 72 persen. Sedangkan tahun 2016 sampai dengan tahun 2019, realiasi retribusi daerah mengalami penurunan masing-masing sebesar 56,4 persen pada tahun 2016, 9 persen tahun 2017, 4,7 persen tahun 2018 dan penurunan tertinggi pada tahun 2019 sebesar 55,3 persen.

2. Tingkat efektivitas pemungutan retribusi daerah tahun 2014 sebesar 114,4 persen atau termasuk kategori sangat efektif. Sedangkan tingkat efektivitas pemungutan retribusi daerah tahun 2015 dan 2016 masing-masing sebesar 89,1 persen dan 88,2 persen atau termasuk kategori kurang efektif. Tingkat efektivitas pemungutan retribusi daerah tahun 2017, 2018 dan 2019 masing-masing sebesar 66,9 persen, 74 persen dan 39,9 persen atau termasuk kategori tidak efektif.

3. Kontribusi retribusi daerah terhadap PAD tahun 2014 sampai dengan tahun 2019 masing-masing sebesar 16,82 persen, 22,83 persen, 7,88 persen, 6,16 persen, 6,76 persen dan 2,69 persen. Pada tahun 2014, retribusi daerah memiliki kontribusi kurang baik terhadap PAD, tahun 2015 memiliki kontribusi yang cukup baik, dan tahun 2016 sampai dengan 2019 kontribusi retribusi daerah terhadap PAD sangat kurang baik.

4. Prediksi penerimaan retribusi daerah untuk tahun 2020 sampai dengan tahun 2022 diperoleh rata-rata penerimaan untuk 3 (tiga) tahun yakni Rp19.474.844.122 atau akan terjadi peningkatan rata-rata sebesar 33 persen per tahun. Sementara itu prediksi penerimaan PAD diperoleh rata-rata penerimaan sebesar Rp342.948.257.802 atau akan terjadi peningkatan rata-rata sebesar 33 persen per tahun.

\section{DAFTAR PUSTAKA}

Adisasmita, Rahardjo. 2011. Manajemen Pemerintah Daerah. Graha Ilmu, Yogyakarta.

Arikunto, Suharsimi. 2013. Prosedur Penelitian Suatu Pendekatan Praktik. Rineka Cipta, Yogyakarta.

Astini, Yuli., Rusdi., \& RA Hannah Syabaneva. 2017. Pengawasan, Kesadaran Retribusi Serta Sarana dan Prasarana Sebagai Penyebab Tidak Tercapainya Target Penerimaan Retribusi Pelayanan Sampah Di Kabupaten Lombok Barat. JAA, Vol. 2, No. 1, hal: 62-75

Badan Pusat Statistik Kabupaten Lombok Utara. 2019. Kabupaten Lombok Utara Dalam Angka 2019

Halim, Abdul. 2004. Bunga Rampai Manajemen Keuangan Daerah Edisi Revisi. UPP UMP YKPN, Yogyakarta.

https://www.antaranews.com/berita/934946/lombok-utara-pulihkan-456-potensipajak-terdampak-gempa

https://www.suarantb.com/jumlah-tka-di-klu-berkurang/

Kisnawati, Baiq., \& Irianto. 2016. Estimasi Penerimaan Pendapatan Asli Daerah (PAD) di Kabupaten Lombok Utara. Jurnal valid, Vol 13, No. 3, hal: 326-332

Nurcholis, Hanif. 2007. Teori dan Praktik Pemerintahan dan Otonomi Daerah. PT Grasindo, Jakarta.

Pemerintah Daerah Kabupaten Lombok Utara. 2014. Laporan Keuangan Pemerintah Daerah Kabupaten Lombok Utara Tahun 2014.

Kabupaten Lombok Utara Tahun 2015

2015. Laporan Keuangan Pemerintah Daerah 2016. Laporan Keuangan Pemerintah Daerah

Kabupaten Lombok Utara Tahun 2016

Kabupaten Lombok Utara Tahun 2017

2017. Laporan Keuangan Pemerintah Daerah 2018. Laporan Keuangan Pemerintah Daerah

Kabupaten Lombok Utara Tahun 2018
Regional
Retribution and

Revenue

11 
Peraturan Daerah Nusa Tenggara Barat Nomor 5 Tahun 2018 Tentang Retribusi Daerah

Peraturan Pemerintah Republik Indonesia Nomor 12 Tahun 2019 Tentang Pengelolaan Keuangan Daerah

Safrita. 2014. Pengaruh Retribusi Daerah Terhadap Pendapatan Asli Daerah Kota Jayapura. Jurnal Future, hal 102-114.

Sartika, Dewi, Atika Ulfa, \& Andre Ilyas. 2019. Analisis Potensi Penerimaan Pajak Daerah Dan Retribusi Daerah Terhadap Pendapatan Asli Daerah (PAD) Kabupaten/Kota Di Provinsi Sumatera Barat. Jurnal Ekonomi \& Bisnis Dharma Andalas, Volume 21 No. 1, hal: 32-53

Sipakoly, Selly. 2016. Analisis Pengaruh Serta Pertumbuhan Pajak Daerah Dan Retribusi Daerah Terhadap Pendapatan Asli Daerah Kota Ambon. Jurnal Maneksi, Vol 5, No. 1, hal: 32-43

Subagyo, Pangestu. 2013. Forecasting: Konsep dan Aplikasi. Edisi Tiga Cetakan Pertama. BPFE, Yogyakarta.

Sudarmana, I Putu Agus., \& Gede Mertha Sudiartha. 2020. Pengaruh Retribusi Daerah dan Pajak Daerah Terhadap Pendapatan Asli Daerah di Dinas Pendapatan Daerah. E-Jurnal Manajemen, Vol. 9, No. 4, hal: 1338-1357

Undang-Undang Republik Indonesia Nomor 23 Tahun 2014 Tentang Pemerintahan Daerah

Undang-Undang Republik Indonesia Nomor 28 Tahun 2009 Tentang Pajak Daerah Dan Retribusi Daerah

Undang-Undang Republik Indonesia Nomor 32 Tahun 2004 Tentang Pemerintahan Daerah

Undang-Undang Republik Indonesia Nomor 33 Tahun 2004 Tentang Perimbangan Keuangan Antara Pemerintah Pusat Dan Pemerintahan Daerah

Undang-Undang Republik Indonesia Nomor 9 Tahun 2015 tentang Perubahan Kedua atas Undang-Undang No. 23 Tahun 2014 tentang Pemerintahan Daerah

Yuliastuti, Ida Ayu Nyoman, \& Ni Luh Putu Sandrya Dewi. 2017. Analisis Efektivitas Dan Kontribusi Retribusi Daerah Terhadap Pendapatan Asli Daerah (PAD) Kota Denpasar. Jurnal Riset Akuntansi JUARA, Vol.7 No.1, hal: 91-102. 